\title{
The Search for Evidence: The Relics of Martyred Saints and Their Worship in Cordoba after the Council of Trent ${ }^{1}$
}

\author{
Cécile Vincent-Cassy
}

The city of Cordoba in southern Spain is famous today for its Muslim history, having been between 929 and 1031 the capital of the Umayyad caliphate, its importance symbolized by its Great Mosque. Because the Mezquita was already regarded as one of the most accomplished monuments of all time, it was not destroyed after the 'Reconquista' of Cordoba by the Christian king Fernando III of Castile in 1236, but converted into the centre of the Cordoban diocese, the cathedral. In the sixteenth century, Emperor Carlos V made a significant modification to the expansive Muslim structure, ordering a nave to be built in the Renaissance style in the centre of the building. Despite these changes, this cathedral remains to this day the embodiment of the splendor and refinement of Muslim art in Spain and a testament to the richness of its past. But for the Cordoban Catholics of the early modern period this was not always easy to accept. In fact, during the Counter-Reformation, the local Catholic authorities in Cordoba were called upon to prove the continuity of the Christian past in spite of major evidence to the contrary. To them it became intolerable that their town, a part of the monarchy ruled by the Catholic king Felipe II, symbolized the dark ages of Spanish Christianity to the entire Catholic world. In the context of the sometimes tense relationship between local and universal religion, ${ }^{2}$ from the last quarter of the sixteenth century to

1 I want to warmly thank Katrina B. Olds and Guy Lazure for their comments and critiques, indispensable in the preparation of this chapter and their help with translations.

2 On this topic, see David Gentilcore, From Bishop to Witch: The System of the Sacred in Early Modern Terra d'Otranto (Manchester: Manchester University Press, 1992); Alyson M. Poska, Regulating the People: The Catholic Reformation in Seventeenth-Century Spain (Leiden: Brill, 1998); Katrina B. Olds, 'How to Be a Counter-Reformation Bishop: Cardinal Baltasar de Moscoso y Sandoval in the Diocese of Jaén, 1618-1646', Sierra Mágina: Revista universitaria, 12 (2009): pp. 197-213; Simon Ditchfield, 'Martyrs on the Move: Relics as Vindicators of Local Diversity in the Tridentine Church', Studies in Church History, 30 (1993): pp. 283-94; and Ditchfield, Liturgy, Sanctity and History in Tridentine Italy: Pietro Maria Campi and the Preservation of the Particular (Cambridge: Cambridge University Press, 1995).

(C) CÉCILE VINCENT-CASSY, 2016 | DOI 10.1163/9789004324329_006

This is an open access chapter distributed under the terms of the CC-BY-NC-ND License. 
the second half of the seventeenth century, proving the continuity of the Christian past from the Roman period to the high Middle Ages, through the long Islamic period, became a major preoccupation for Catholic scholars in Cordoba. Only proof of the existence of martyrs persecuted by Christian enemies - whether Roman or Umayyad - would establish that fact irrefutably. Some digging, orchestrated by local Catholic authorities and scholars, would help them to find this proof. In 1575 the restoration works in the parish church of San Pedro unearthed a sepulcher, which contained many skulls and human bones and matched with a stone dating from the Roman period kept in another church. Five names were inscribed on this gravestone: Faustus, Januarius, Marcial, Zoillus and Acisclus. The bones were immediately identified as the relics of the first three of these men, who were Hispano-Roman martyrs, and although their authenticity was not examined in depth, the bishop could quickly authorize their worship. In fact, by virtue of a traditional episcopal prerogative reaffirmed by the Council of Trent (1545-63), Pope Gregory XIII let the bishop of Cordoba, with the advisory Provincial Council of Bishops of Castile that he summoned, adjudicate the relics. Thanks to the mention of the saints in the Martyrologium Romanum and the hagiographies provided by ancient sources, the authentication of the relics was easy. It allowed the bishop of Cordoba to obtain a quick positive sanction by the Holy See, permitting him to authorize the worship of the relics in 1583 . The reference to these martyrs in the most famous collective hagiography of early modern times, the Flos sanctorum published by the Jesuit Pedro de Ribadeneira, in the second volume of the work dedicated to santos extravagantes, attests to the acceptance of their legitimacy by $1601 .{ }^{3}$ Ribadeneira, who was writing in Rome, at the centre of the Catholic world, summarized why and how the authenticity of these relics had been resolved by a 1583 provincial council.

In martyred saint Eulogius' texts there are frequent references to the church of these saints in Cordoba, where their bodies were kept and worshipped, and he sometimes calls them the 'three martyrs'. The Martyrologium Romanum set their feast on October 13th, even though St Isidorus, Bede and Usuardus mentioned it on September 28th. On November 21, 1575, while excavating beneath the floor of the church of San Pedro of Cordoba - formerly the cathedral - a thick stone sepulcher with some inscriptions was found. The inscriptions appeared to mention the presence of the martyred saints of Jesus Christ Faustus, Januarius and Marcial, Zoïlus, Acisclus and others. The case was discussed with Pope Gregory XIII, who forwarded it to the provincial council, which met in

3 The santos extravagantes were those who, without being the object of universal worship, had been recorded as part of the Roman Martyrology, published in 1583 . 
Toledo in 1582. The council was headed by Cardinal Gaspar de Quiroga, Archbishop of Toledo, and on January 23, 1583, it declared that the relics in question had to be worshipped by all Christians as relics of saints, who reign with God in heaven. The martyrdom of these saints is related by Marineo Siculo, who cites ancient memorials and books, and also by

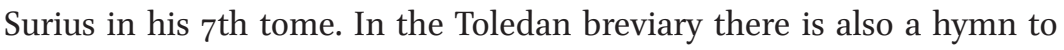
their victories and praises. ${ }^{4}$

Since, on the one hand, St Acisclus (Acisclo), whose name was among those mentioned on the inscribed stone, was already the patron saint of the town together with his sister, St Victoria, and his relics were supposedly kept in the iglesia de los Mártires del Colodro (church of the martyrs), and on the other hand, St Zoïlus' relics were venerated in the monastery of the same name in the town of Carrión, Castile, the discovery was partly embarrassing, as it contradicted other churches' claims. So, in 1583 the provincial council left the matter open to the possibility of a revision, stating that the celebration of the feast of Saints Faustus, Januarius, Marcial and 'other' martyrs, without specifying their names, as well as the feast of the 'invention' of the sacred relics on November 25 th, would now be authorized in the city of Cordoba. Bernardo de Fresneda, bishop of Cordoba, also ordered in the meantime that many other relics be properly stored and displayed. This order was fulfilled in 1584 with the solemn installation of the santa arca (sacred case) of the relics on the martyrs' altar built inside the church of San Pedro. ${ }^{5}$ As previously stated, five names

4 'En el martir san Eulogio muchas vezes ay mencion de la Yglesia destos santos de Cordoba, donde se conservavan, y eran reverenciados sus cuerpos, llamandola algunas vezes los tres martires. Dello haze mencion el Martirologio Romano a treze de Otubre, aunque san Isidoro, Beda y Usuardo ponen su fiesta a 28 de Setiembre. El año de 1575 a ventiuno de Noviembre, cavando un cimiento de la Yglesia de san Pedro de Cordoba (que fue antiguamente Catedral) se descubrio un sepulcro de piedra tosca con ciertas letras, que leidas señalavan estar alli los santos martires de Iesu Christo, Faustus, Ianuario, y Marcial, Zoylo, y Acisclus, y otros: y aviendose consultado el negocio con el Papa Gregorio XıII su Santidad lo remitio al Concilio Provincial, que se celebró en Toledo, año de 1582. Presidiendo en el don Gaspar de Quiroga, Cardenal y Arçobispo de Toledo, y a los 23 de Enero de 1583 declaro el Concilio, que las tales reliquias devian ser reverenciadas de todos los fieles Christianos, como reliquias de Santos, que reynan con Dios en el cielo. El martirio destos Santos sacò Marineo Siculo, de los libros y memorias antiguas, y se refiere en el septimo tomo de Surio: y en el Breviario Toledano ay un himno en que se cantan sus alabanças y vitorias'. Pedro de Ribadeneira, Segunda parte del Flos sanctorum, o Libro de las vidas de los santos. En la qual se contienen las vidas de muchos Santos de todos estados, que comunmemnte llaman Extravagantes (Madrid: Luis Sánchez, 1624 [1601]), p. 104.

5 Martín de Roa, Flos sanctorum. Fiestas, i santos naturales de la Ciudad de Cordoua (Seville: Alonso Rodríguez Gamarra, 1615), 'Historia de la invencion de los santos Martires Fausto, Ianuario, Marcial, Zoilo, i Acisclo, con otros muchos', fols. 163r-177r. 
were mentioned on the stone discovered in 1575, but only three of them were then linked to the sacred bones. Many of the relics found with the stone were set aside to be examined further at a later date: these were the 'others' mentioned by Pedro de Ribadeneira in his text. They would be the subject of another promotional campaign at the beginning of the seventeenth century aiming to identify them as martyred saints of the Muslim period.

However, for those who did not share the belief in the continuity of the Cordoban Christian past, the veracity of these relics, especially those that had not been identified at once, was questionable. ${ }^{6}$ In the wake of Protestant attacks on the authenticity of relics, disagreement arose throughout the Catholic world about the relics of saints and martyrs from the early Chrisitian period, which could be used to prove the continuity and 'excellence' of some dioceses' Christianity. In Spain, some of the major scholars of the reign of Felipe II took part in these debates. The Cordoban relics were a major point of contention, as it was crucial for the Spanish crown to demonstrate the perfection of its Catholicity despite eight centuries of Islamic presence in Spain.

Some lines of the Historia eclesiástica de España, published by Francisco de Padilla in $1605,{ }^{7}$ called into question the existence of authentic relics belonging to the martyrs of Cordoba who had been subject to Roman as well as to Muslim persecution. Padilla was part of a network of scholars and declared that he was indebted to Ambrosio de Morales, Felipe II's famous chronicler, Juan de Marieta, author of the Historia eclesiástica de todos los santos de España (1594), and Alonso de Villegas, who had mentioned the relics in the second volume of his already renowned Flos sanctorum (Toledo, 1584). ${ }^{8}$ But above all, Padilla noted that another royal chronicler, Esteban de Garibay, had affirmed that the

6 'If saint - whether canonized or merely aspiring - constituted an ambiguous and contested category, so did relic, as the criteria and procedures for evaluating the physical remains of purported saints remained ill-defined'; Katrina B. Olds, 'The Ambiguities of the Holy: Authenticating Relics in Seventeenth-Century Spain', Renaissance Quarterly, 65 (2012), p. 137.

7 Francisco de Padilla, Historia eclesiástica de España. Primera parte que contiene cinco centurias en que se trata del principio y progressos que tuuo la religion christiana en España (Málaga: Claudio Bolan, 1605). On Padilla's history of the Spanish Church, see Katherine Van Liere, 'Renaissance Chroniclers and the Apostolic Origins of Spanish Christianity', in Sacred History: Uses of the Christian Past in the Renaissance World, (ed.) Katherine Van Liere, Simon Ditchfield and Howard Louthan (Oxford: Oxford University Press, 2012), pp. 121-44; Van Liere also dedicates a chapter to Ambrosio de Morales, asserting that 'Morales' ultimate aim was to reaffirm, not to undermine, most of the legends of first-century Spanish Christianity that had become commonplace in the national chronicles since the 1530s'; p. 139.

8 'Estos Santos Martires comunmente estan reputados por hijos de San Marcelo, y por tales los cuentan el Flos Sanctorum, Vaseo, Morales, y Marieta, y escriven el Maestro Alonso de Villegas y Ambrosio de Morales, ser comun y antigua Tradicion en Cordoba'; Padilla, Historia eclesiástica, fol. 203v. 
bodies of the martyrs had been transported to Toulouse, in France, where they were venerated in the church of St Saturnin. ${ }^{9}$ Nevertheless, neither Esteban de Garibay nor Ambrosio de Morales had any real proof that they could produce. Padilla, like the other scholars, does not even mention the inscriptions that were present on the stone of the sepulchers.

But beginning in 1602-03, when an epidemic of plague struck Cordoba, local scholars started to bring forth some new evidence and to build an argument to demonstrate the authenticity of the 'other' bones. The wealth of relics was a treasure that the contemporary Cordoban historians would help to reveal by producing commentaries on so-called rediscovered ancient sources, mainly textual forgeries that they believed were true. In the case we are examining, the main source used by the scholars was the Memorialis Sanctorum, written by the Cordoban St Eulogius, rediscovered at the end of the sixteenth century and reedited by Ambrosio de Morales in $1574 .{ }^{10}$ Throughout the seventeenth century, they would enrich, excite and restore the devotion and affection of their fellow citizens for the 'forgotten' local martyr saints by giving stories and bodies to these names found on the inscribed stones of old graves.

This phenomenon is similar to the one observed in the case of the saints of Arjona a few decades later, ${ }^{11}$ the Sacromonte of Granada, ${ }^{12}$ and the Santo

'Esto dize Ambrosio de Morales, y es cosa sin duda aver en aquella Iglesia reliquias destos Santos Martires, que parte dellas fueron halladas el año de mil y quinientos y setenta y siete (de que se tratará en su propio lugar) aunque Estevan de Garivay ... dize desta manera. En la ciudad de Córdoba Ilustrada no solo con letras y milicia, pero aun con mucha Santidad, padecieron martirio por Nuestra Santa Fe San Acisclus y su hermana Santa Victoria, cuyos cuerpos bienaventurados están en grande veneración en Francia, en la Ciudad de Tolosa, en la Iglesia de San Saturnino'; Padilla, Historia eclesiástica, fols. 205v-206r. Eulogio de Cordoba, Diui Eulogii Cordubensis martyris. Opera studio et diligentia (Alcalá de Henares: J. Íñiguez de Lequerica, 1574).

11 Cécile Vincent-Cassy, 'Los santos re-fundadores. El caso de Arjona (Jaén) en el siglo XVII', in L'imaginaire du territoire en Espagne et au Portugal (XVI $I^{e-X V I I}{ }^{e}$ siècles), (ed.) François Delpech (Madrid: Casa de Velázquez, 2008), pp. 193-214. Also see Katrina B. Olds, 'Visions of the Holy in Counter-Reformation Spain: The Discovery and Creation of Relics in Arjona, c.1628', in The Vision Thing: Studying Divine Intervention, (ed.) William A. Christian and Gábor Klaniczay (Budapest: Collegium Budapest, 2009), pp. 135-56. For a framework of the contemporary forgeries, see Olds, Forging the Past: Invented Histories in CounterReformation Spain (New Haven: Yale University Press, 2015); and Olds, 'The False Chronicles, Cardinal Baronio and Sacred History in Counter-Reformation Spain', The Catholic Historical Review, 100 (2014): pp. 1-26; and Olds, 'The Ambiguities of the Holy'.

12 A. Katie Harris, 'Forging History. The Plomos of Granada in Francisco Bermúdez de Pedraza's Historia eclesiástica', Sixteenth-Century Journal, 30 (1999): pp. 945-66, and her book: From Muslim to Christian Granada: Inventing a City's Past in Early Modern Spain (Baltimore: Johns Hopkins University Press, 2007). 
Rostro of Jaén about which a local scholar named Juan Acuña del Adarve published a hefty tome in $1637 .^{13}$ Acuña del Adarve was connected to the local religious authorities at the beginning of the seventeenth century, and his treatise is an apology for a particular image, presented as the end point of a sacred itinerary that began in Jerusalem. The Santo Rostro of Jaén is believed, he says, to be a relic of the vera icona, the true image that resulted from the impression at Calvary of Christ's sweat and bloody face on Veronica's veil. This relic had been the object of great devotion in Jaén since the late Middle Ages. It attracted one of the most important pilgrimages in Spain and was considered by Catholic authorities in Jaén to have the same value as the Roman Holy Face. At stake was the idea that the local cult would compete with the Roman cult. But with his treatise, Acuña del Adarve sought to exalt the relic of Jaén without suggesting that the Roman one was of less value. On the contrary, he raised the local relic, and the local cult, to the same rank as the Veil of Veronica kept in St Peter's Basilica, at the very heart of the Catholic Church. For this purpose, the author had first and foremost to prove the authenticity of the Santo Rostro of Jaén, and to this end he deemed no strategy unworthy. As he could not base his demonstration on the miracles that the relic had produced - they were in fact non-existent - he based it on the veneration shown for the object by local inhabitants since time immemorial. In his treatise, this long-standing and profound devotion, which could not be doubted, became a proof of divine truth. The discursive structure of this text rested on the idea that the veracity of this relic spoke to the true devotees. Acuña del Adarve, a local scholar of the diocese adjoining that of Cordoba, faced the same theological problem of evidence that the scholars faced in Cordoba and, of course, elsewhere in the Catholic world. To address this problem, they wrote local histories anchored in sacred traces and outlined a geography based on Christian vestiges that they knew very well because they were themselves living there. This position allowed them to speak as true witnesses, and even as true devotees, with a true discourse that they claimed to have. In fact, their challenge was to prove the authentic presence of the Savior in their land, their diocese, their town, in

Juan Acuña del Adarve, Discursos de las effigies y verdaderos retratos non manufactos del santo rostro y cuerpo de Christo (Villanueva de Andújar: J. Furgolla de la Cuesta, 1637). The book was commissioned by the bishop, and is dedicated to him: 'Al Eminentissimo, y Reverendissimo Señor don Baltasar de Moscoso y Sandoval, Presbytero Cardenal de la Santa Iglesia de Roma, del titulo de Santa Cruz de Hierusalen, Obispo de Jaen, del Consejo de su Magestad'. On this treatise see Cécile Vincent-Cassy, 'Linventaire des empreintes sacrées. Le discours de Juan Acuña del Adarve sur les Saintes Face (Jaén, 1637)', in Folclore y leyendas en la península ibérica. En torno a la obra de François Delpech, (ed.) Hélène Tropé and María Tausiet (Madrid: csic, 2014), pp. 81-98. 
short their patria, going back to apostolic times. The easiest strategy for them was then to found their whole discourse upon the materiality of some tangible evidence: relics venerated by them and by their fellow devotees. But again, they had to identify that these objects did indeed belong to Christians and were not the bones of non-Christian people. The most direct way to do so would be to identify miracles produced by the relics. But miracles had to be proven too and, as we see in the example of the Santo Rostro, sometimes they were non-existent. So, the power of devotion since time immemorial was used as an argument of last resort. All these authors of treatises confronted the religious objects, relics and images of their lands, trying by all possible means to reveal their truth. In the case of Cordoba, scholars linked to the diocesan authorities had to develop strategies to identify the 'other' relics discovered in 1575 that were different from the ones Acuña del Adarve had used. They claimed that the plague was a punishment for the lack of devotion their fellow citizens showed for the relics.

Some revelaciones made to Andrés de Roelas, parish priest of San Pedro of Cordoba, shortly after the discovery of the new relics in his church in 1575, were directly used to promote their worship beginning in 1601-02. These 'revelations' were recorded in the deposition made by the priest to the diocesan council of Cordoba in 1578, and this text constitutes a real piece of bravura in the creation of a primitive Christian past. But the text of the Revelaciones was kept secret by a priest named Juan del Pino until the beginning of the following century. Juan del Pino was one of the authors of the diocesan liturgical office, which was published for the first time in the Officia propria Cordvbensis ecclesiae: D.N.P.P. Gregorij XIII et Clementis VIII, auctoritate approb. ${ }^{14}$ As we shall see, the Revelaciones first served to create a link between the martyred saints and the Cordoban people and to authenticate some new relics. By doing so, it imposed upon the Cordoban people the intercession of those saints and their patronage. However, in a second phase, the archangel Raphael, medicina Dei, intervening in the text of the Revelaciones to excite devotion to the martyr saints, was finally recognized himself, even more so than the martyr saints, as the true custodian of the community of Cordoba: his presence, contrary to that of the martyr saints, was undeniable.

In the first and second 'revelations' made to Father Andrés de Roelas, five knights dressed all in white appear. In the text, which later on circulated as part of the short work by Pedro Díaz de Ribas printed in the middle of the seventeenth century by commission of the city of Cordoba, ${ }^{15}$ we learn that the

14 Cordoba: Gabriel Ramos Bejarano, 1601.

15 Díaz de Ribas, El Archangel S. Rafael. 
first apparition took place on Holy Saturday in 1578. Andrés de Roelas had gone out to take some air because he was not feeling well. The five knights who then appeared to the priest, even though they left no trace of their passage on the ground after their disappearance, were without a doubt the five martyred saints already identified. In fact, Roelas heard one of them say that he recognized the mountain where he had been arrested by the Romans. ${ }^{16}$ These characters also represented the knights of the Apocalypse, that is, prophetic beings. In this vision, they said to the parish priest that the city would undergo great hardship ${ }^{17}$ and that the remedy would be to honor the other recently discovered relics of the martyred saints. Their request underscored, first and foremost, the insufficient honor that was being paid to the sacred bones found in the church of San Pedro. It must be said that the absence of reliquaries worthy of the name contradicted the text of the decree given at the final session of the Council of Trent on saints, relics and images. ${ }^{18}$ Reliquaries would have permitted the worship of the saints to be related to an object. ${ }^{19}$

A month later, as it is told in the Revelaciones, Father Roelas reported a second vision, which he had while asleep, to the rector of the Cordoban church of La Magdalena, as he stood next to him in a procession to pray for rain, with the holy relics of the martyrs at his side. The Revelaciones insisted on the importance of placing the relics in reliquaries where they could be seen and venerated. ${ }^{20}$ In a third vision, a young man dressed in a white robe, compared

16 'Qué grande montaña era esto por aquí quando á mí me prendieron'; Revelaciones del Venerable Presbytero, in Díaz de Ribas, El Archangel S. Rafael, fol. 22r.

17 'Enfermedades, trabajos y flujos de sangre'; Revelaciones del Venerable Presbytero, in Díaz de Ribas, El Archangel S. Rafael, fol. 22r.

For a discussion of this text, see Pierre A. Fabre, Décréter l'image? La XXV esession du Concile de Trente (Paris: Les Belles Lettres, 2013).

19 'Stripped of its reliquary, the protective casing that signaled the presence of the holy, or severed from the human communities and memories that endowed the remains with meaning, the relic became a mere bone, the anonymous remains of any common mortal'; Katie Harris, 'Gift, Sale and Theft. Juan de Ribera and the Sacred Economy of Relics in the Early Modern Mediterranean', Journal of Early Modern History, 18 (2014), p. 206.

This was made at the beginning of the seventeenth century, when the procession of the relics took place during the plague epidemic. Juan del Pino describes the reliquaries, ceremonies and decorations for the feasts celebrated in 1601, in his letter of 1602: 'el cabildo desta yglesia ... acordó ... hazer una Arca que cupiesse en la de mis señores los santos ... y su viril de dentro porque se viessen y gozassen las santas reliquias puestas en el Altar, cubrenla de brocado con quatro cartones muy lindos y redondos de mas de tercia en alto puestos en los quatro lados del arca en los que les yvan pintados muchos santos nuestros muy hermosamente ... y días de julio los llevaron con solemníssima processión y devoción grande a la catedral: duró por lo menos tres horas el llegar alla el adereço de las calles 
by Roelas to the robes of the Commanders of the Military Order of Alcántara, sat for the first time near his bed. The parish priest reported that he asked the still-nameless being who had appear in the night about the utility of the reliquaries. The man in white reprimanded him because he had not believed the five knights in white who had appeared several days earlier. His intervention, according to the account, would serve to put pressure on the ecclesiastical authorities to order a reliquary for the sacred bones of the martyrs that had been found shortly before in the church of San Pedro. The priest was the instrument of the divine word: the relics of the patria's saints were to be honored. ${ }^{21}$ There would be other interventions of this kind. Eventually, Andrés de Roelas received a second visit from the character in the white tunic who had already appeared alone. Only at that point did he reveal his name: Raphael ('I swear by Jesus Christ crucified that I am Raphael, angel whom God has designated as the patron of this town').22 This sentence would be the foundation of a subsequent reconstruction based on the revelations that were commissioned by the municipal authorities and published later in the seventeenth century, at the moment when Raphael was elected patron saint of Cordoba. Throughout this

que infinidad de sedas e ymagines por las paredes, no se puede contar tanto que hizo acordarme del nuestro sacromonte alla tanta aromata in Hierusalem, que se dize de la Reyna Saba; ... hasta colocar la Arca santa en el altar donde se le hizieron los nuebe dias siguientes solemnissimas fiestas y sermones con que sucedió luego la salud tan defensa, donde se tuvieron nuestros sanctos con grande reverencia y devocion de todos hasta el dia y fiesta de nuestros benditissios Fausto, Januario y Martial'; RAH, 9/3666 (105 $\left.{ }^{2}\right)$, letter, [1602].

'Porque tiempo ha de venir que ha de hazer Dios misericordia con este pueblo, por intercession de los huesos destos mártyres; porque han de suceder graves enfermedades, y pestes, y sobre las mugeres fluxos de sangre ... es verdad que con quien lo aveis de comunicar ha sido de opinion contraria, mas no obstante eso dezidselo; y mas os digo, que las enfermedades han de ser tan graves, que habrá necessidad de traer los huesos destos mártyres por las collaciones en procession y por la calles dellas. Y para esto decilde que haga hazer un relicario grande en que sean puestos los huessos destos Mártires; y que sea este relicario con viriles, porque manifiestamente puedan ver los dichos huesos. Yo le dixe que para qué eran aquellos viriles. Respondióme, yo os lo diré, porque Dios es servido que su Imagen y la de su Madre y de sus Santos las tengan los hombres delante de los ojos para que allí le pidan el remedio de sus necessidades y hagan sus devociones. Y así viendo visiblemente los huesos destos martyres pidan á nuestro Señor con mayor devocion el remedio de sus necessidades'; Revelaciones del Venerable Presbytero, in Díaz de Ribas, El Archangel S. Rafael, fol. 23 r.

'Yo te juro por Jesu Christo crucificado que soy Raphael Angel a quien tiene Dios puesto por guarda desta ciudad'; Revelaciones del Venerable Presbytero, in Díaz de Ribas, El Archangel S. Rafael, fol. 24 r. 
text, the patronage of the archangel was intimately linked with the invention of the holy relics of the city martyrs and the promotion of their cult. There are, then, three different moments to keep in mind: $1575^{-83}$, when the new bones were discovered and identified as the relics of martyred saints; 1601-02, when the 'revelations' made to Andrés de Roelas were revealed to the public and the image of the archangel Raphael was used to promote the worship of the martyr saints; and the second half of the seventeenth century, when the archangel Raphael, who had played a role in the identification of the 'other' martyrs, was declared custodio of Cordoba.

Going back to the first period, the reaction of Father Roelas, according to what he says, was to ask for advice from local theologians. He would find them, along with the rector of the church of La Magdalena, at the local Jesuit monastery. Roelas consulted Enrique Enríquez (1535-1608), catedrático at the universities of Cordoba and Salamanca, and another priest named Saeliz, about whom we know little. Through them, he connected with the network of Cordoban 'antiquarians'.

In the second period, the context in which these revelations first circulated (in several manuscripts) is important, since during 1601 and 1602 a terrible plague epidemic was ravaging Cordoba, as well as other parts of the Iberian Peninsula and Europe. Juan del Pino, the priest who had transcribed the revelations of Andrés de Roelas, mentioned in a 1601 letter that the plague had already killed six thousand people in Cordoba. ${ }^{23}$ Since the situation was so dire, the devotion to the martyred saints identified in 1575 was no longer regarded as sufficient to protect the Cordobans. The number of protectors was no match for the danger posed by the epidemic. As usual, a procession was organized, from the church of San Pedro to the cathedral. It took place on the day of the feast of St Argimiro, one of the 'other' holy martyrs whose relics were supposedly preserved in the urn at San Pedro, but which had not been authenticated in 1575 at the same time as the bones of Saints Faustus, Januarius, Marcial, Acisclus and Zoïlus. According to the Crónica general of Ambrosio de Morales, St Argimiro had supposedly been a victim of the Muslims in the ninth century. Perceiving that the illness appeared to taper off following this procession, Juan del Pino decided to present the 'revelations' of Andrés de Roelas which he had kept secret since the time of the deposition. Pino argued for the presumed miraculous power, or effectiveness, of these unauthenticated relics and aimed to provide some proof of identification. In the 'revelations', the

23 'Tres cosas se offrecen que dezir en esta a v. p., la primera, que como dende el año pasado de 601 ha durado en nuestra Cordoba esta terrible enfermedad, en que se abia llevado nuestro señor hasta fin de junio seys mil personas'; RAH, 9/3666 $\left(105^{2}\right)$, [1602]. 
archangel authenticated several of the relics from the church of San Pedro, including that of St Argimiro. He told Andrés de Roelas:

The Provisor [diocesan authority] told you that, if I were to return to you, you should ask me who were those martyrs whom I had spoken to you about. Tell him that they are the ones that the stone says, and many others as well: among them Perfectus Presbitero, and Argimirus Monje, Leovigildus, and Christopher, Victoria, Flora and Maria, Helias, and Hieremias, and others. ${ }^{24}$

These 'revelations' must then be understood as part of the aforementioned battle that was raging among Cordoban scholars to prove the authenticity of the relics found at San Pedro. What was at stake was proving that all the Cordoban martyr saints, not only those from the late Roman period, but also those who had been tortured by the Muslims, were buried together in the same spot as Saints Acisclus, Faustus, Januarius, Zoïlus, Pelagius and Eulogius. The demonstration of the continuity of the Christian past, through the communion of martyrs, was finding its material and 'obvious' translation in the gathering of sacred bones. ${ }^{25}$ By focusing on this corporal evidence, the Cordoban network was considering Spanish history as a continuum beginning with the evangelization of Spain by Santiago and his disciples in the first century. In a way, these 'antiquarians' were constructing a response to what was happening in nearby Granada since the Lead Books of the Sacromonte had been discovered in 1595. They totally rejected the inclusion of the Muslim past as anything but a time of persecutions for Christianity. This is precisely what the Jesuit Martín de Roa (1559-1637) claimed in the prologue of the Flos sanctorum dedicated to the city of Cordoba in 1615:

Either by the power of arms or by voluntary surrender, Cordoba gave way to two foreign Empires, the Roman and the Arab, both enemies of the Christian name. The first attempted to eradicate it altogether, while the others desired to do the same. The former looked for or created occasions

24 'el Provisor te dixo, que si a ti bolviesse que me preguntases quien eran aquellos Mártires de quien yo te avia tratado. Dile que los que dize la piedra son, y otros muchos más: entre los quales están, Perfecto Presbitero, y Argimiro Monje, Leovigildo, y Christoval, Victoria, Flora y Maria, Helías, y Hieremías, y otros'; Revelaciones del Venerable Presbytero, in Díaz de Ribas, El Archangel S. Rafael, fol. 24r.

25 We have discussed the question of the communion of saints and of the collective worship in Olivier Marin and Cécile Vincent-Cassy (eds.), La Cour céleste. La commémoration collective des saints. Entre accumulation et communion ecclésiale (Turnhout: Brepols, 2015). 
to do it, while the latter took them whenever they could find them; the Romans because the cross scandalized them, the Moors because of their hatred for Christians. In both periods Christians suffered persecutions which they endured until they vanquished by dying for Jesus Christ. The first ones were St Acisclus and St Vitoria, siblings, Patrons of this city; Saints Faustus, Januarius, Marcial and Zoïlus with nineteen companions, Sandalius and Secundinus along with many others that Breviaries and Spanish Calendars of Saints refer to, and general martyrologies name. The first when Rome ruled in Spain; the rest, in much greater number, when the Arabs reigned. I do justice to the memory of all of them, as taken from the reports of our ancient histories, printed and manuscript Flores Sanctorum, breviaries from centuries past and present, and especially from the glorious Doctor St Eulogius, eyewitness to their triumphs and their historian, strength of the Martyrs' fortress in their battles, their brother in arms, victor, and Martyr himself. ${ }^{26}$

The author of these lines, Martín de Roa, was a zealous defender of the greatness of Andalusia's Christian past. As a member of the circle of Cordoban scholars linked to the diocesan authorities and of the Society of Jesus, he became a key figure in the seventeenth-century promotion of the cults of local martyr saints, which finally imposed Raphael as the protector of the city.

Roa has been a major figure in the Spanish 'Republic of Letters', occupying an eminent place among Góngora and Ambrosio de Morales, Bernardo José de Aldrete, the author of Del origen y principio de la lengua castellana (1606), and

26 'Dio silla Cordoba, ya por fuerça de armas, ya por entrega de voluntad, a dos Imperios estraños Romano, i Arabe, enemigos anbos del nonbre Christiano. Procuravan los unos acabarlo de todo punto, los otros desseavanlo: buscavan aquellos las ocasiones, i hazianlas a mano para hazerlo: tomavanlas estotros quando las hallavan. Los Romanos por el escandalo de la Cruz, los Moros por el odio a los Christianos. Padecieron estos en anbos tienpos persecucion, i siguieronla hasta vencer muriendo por Iesu Cristo. Los primeros San Acsiclo, i Santa Vitoria ermanos, Patronos de esta ciudad: los santos Faustus, Ianuario, Marcial, Zoïlus con diez i nueve conpañeros, Sandalio, i Secundino, con muchos otros, que refieren Breviarios, i Santorales de España, i nonbran generales Martirologios. Estos inperando Roma en España: los demas, i en mucho mayor numero, reinando los Arabes en lo mas della. Hago de los unos, i de los otros justa memoria, sacada de memorias antiguas de nuestras historias, Flos Sanctorum inpressos, i escritos de mano, Breviarios de siglos passados, i presentes: i especialmente del glorioso Dotor S. Eulogio, testigo de vista de sus triunfos, e historiado dellos: despertador, i esfuerço de la fortaleza de los Martires en sus batallas, el tambien compañero en ellas, vencedor, i Martir'; Martín de Roa, Flos sanctorum, s.f. 
the Sevillian Rodrigo Caro, all of whom he knew and visited frequently. Although he is far from being unknown to current scholars, we are still waiting for a general synthesis of his role in the community of Spanish 'antiquarians'. He was one of the principal figures in the creation of historias particulares (local sacred histories) linked to the post-Tridentine liturgical revision, a phenomenon that has been explored in detail by scholars since the pioneering work of William A. Christian and Simon Ditchfield. ${ }^{27}$

Born in Cordoba, Martín de Roa spent his entire life in Andalusia, residing in his birth place but also in Montilla, Baeza, Seville, Jerez de la Frontera and Málaga. His bibliography was established by Sommervogel ${ }^{28}$ and Simón Díaz, ${ }^{29}$ who were both inspired by the Bibliotheca Hispana Nova of Nicolás Antonio $(1617-84),{ }^{30}$ before being taken up by Estanislao Olivares in a 1994 article. ${ }^{31}$ Among Roa's many works, a group of printed texts was dedicated to local saints. These histories were probably all written between 1612 and 1615 but printed later on. A letter sent to Roa in January 1613 by the General of the Company of Jesus mentions the liberty he was given to devote himself to his 'studies'. This is how, after being released from his duties as rector of the college of Écija, Roa settled in Cordoba and began publishing. ${ }^{32}$ The Flos sanctorum,

27 William A. Christian, Local religion in sixteenth-century Spain (Princeton: Princeton University Press, 1981). Also Christian, Moving Crucifixes in Modern Spain (Princeton: Princeton University Press, 1992). Simon Ditchfield, Liturgy, Sanctity and History. Also see Van Liere, Ditchfield and Louthan (eds.), Sacred History.

28 Carlos Sommervogel and Augustin and Aloys de Backer, Bibliothèque de la Compagnie de Jésus (Louvain: Éditions de la Bibliothèque SJ Collège philosophique et théologique, 1960) [Brussels, Paris: 1853-61].

29 José Simón Díaz, Jesuitas de los siglos XVI y XVII, escritos localizados (Madrid: FUE, 1975).

30 Nicolás Antonio, Bibliotheca hispana, sive Hispanorum qui usquam unquamve sive latina, sive populari, sive aliā quāvis linguā scripto aliquid consignaverunt notitia (Rome: N.A. Tinassii, 1672).

'Martín de Roa, S.J. (1559-1637). Biografía, Escritos', Archivo Teológico Granadino, 57 (1994): pp. 139-236. See also Jorge Grau Jiménez, 'Un epigrama no censado de Martín de Roa (1586)', Cuadernos de filología clásica. Estudios latinos, 24 (2004), pp. 319-32; Antonio Martín Pradas and Inmaculada Carrasco Gómez (ed.), Martín de Roa. Historia de la Provincia de Andalucía de la Compañía de Jesús (1553-1662), (Écija: Asociación de Amigos de Écija, 2005); Jorge Grau Jiménez, 'Nueva revisión del catálogo de la obra de Martín de Roa, SJ', in Wenceslao Soto Artuñedo (ed.), Los jesuitas en Andalucía. Estudios conmemorativos del 450 aniversario de la fundación de la provincia, (ed.) Wenceslao Soto Artuñedo (ed.) (Granada: Universidad de Granada, 2007): pp. 399-413.

32 '[ya] se hallará libre [de rectorado del colegio de Écija] y en Córdoba atendiendo a su estudio'; Archivium Romanum Societatis Iesu [ARSI], Baetica 4.11, fol. 3, quoted by E. Olivares, 'Martín de Roa (1559-1637)', p. 161. 
fiestas $i$ santos naturales de la ciudad de Cordoua, which could be called his magna opera hagiographica, was printed in Seville in $1615,{ }^{33}$ while the collective hagiography dedicated to the patron saints of Jerez de la Frontera, Santos Honorio, Eutichio, Estevan, patronos de Xerez de la Frontera, came out in 1617. A few years later, in 1622, he published a history of Málaga entitled Malaga: su fundacion, su antiguedad eclesiastica i seglar, sus santos Ciriaco i Paula. In 1629, Roa successively came out with a monograph on the Monasterio antiguo de San Cristoval en Cordoba and a book on the saints of Écija, Ecija, sus santos, su antiguedad eclesiastica $i$ seglar. Finally, in 1636, shortly before his death, he sent to the presses his translation of his Antiguo Principado de Cordoba en la España Vlterior o Andaluz, published in 1601 in Latin. ${ }^{34}$ As we can observe, Martín de Roa expended tremendous energy in linking his own times to those of the primitive local Church, bringing to the fore the traces that the early Church had left in each particular patria. What he attempted to demonstrate, just like other 'antiquarians' working on local churches, was that the blood of Christian martyrs had irrigated, penetrated and infiltrated the soil, the very earth to which they belonged, and this fact sanctified that soil for eternity. This is why, in the Flos sanctorum dedicated to the saints of Cordoba, the author emphasized the proto-martyrs of that city, St Acisclus and St Victoria, its patron saints. In the preamble to their hagiography, he explained that their sacrifice, at the beginning of the fourth century, prepared a fertile ground for the miraculous plants that the land had produced since then. ${ }^{35}$ In other words, his discourse was built on the idea that the martyrs' blood had forever converted Cordoba as a whole to the History of Redemption. From this perspective, the traces left by the Muslims - who had occupied this land for six centuries, until the kingdom of Cordoba was reconquered in the thirteenth century - were

33 Martín de Roa, Flos sanctorum.

34 Amongst his renowned books, there is also the Estado de los bienauenturados en el Cielo, de los niños en el Limbo, de los condenados en el Infierno of 1624 and the Beneficios del Sto. Angel de Nuestra Guarda of 1632.

'Consagraron aquí con sus huellas, las plaças, i calles, por donde ahora andamos; las aguas, que bevemos, el rio que gozamos, las casas donde vivimos. Fueron los primeros, que regaron con su sangre este suelo; i con sus preciosas Reliquias fertilizaron esta tierra: de manera, que produxo milagrosas plantas de toda suerte de gentes: que trasplantadas en el Cielo, son parte de aquel celestial paraiso: i apacientan con la hermosura de los frutos de sus excelentes virtudes, la vista, i animo de sus moradores: $\mathrm{i}$ con el verdor de sus ramas, esto es con el valor de su intercession, hazen sonbra a la tierra, donde anparados sus ciudadanos, hallan escudo contra los golpes de fortuna, remedio en todos los males desta vida, defensa contra los demonios, i entrada con Dios'; Martín de Roa, Flos sanctorum, fol. $157 \mathrm{v}$. 
somehow traces of a Christian past. Martín de Roa wanted to demonstrate that the centuries of Islamic rule in Al-Andalus, like the Roman period, had been a Christian era, through martyrdom. The evidence for this had to be reaffirmed, as the Christian sacrifice was inscribed in the objects left in the soil: relics, stones, medals. Martín de Roa's prolific works have to be explained and understood, then, as a whole within the context of the discovery of the forged Lead Books in the nearby town of Granada at the end of the sixteenth century. These Lead Books asserted the continuity of the Christian past in Andalusia and beyond, in all of Spain. ${ }^{36}$ In this context, we can regard the making of sacred history as a process of revelation based on the sacred traces found in the different lands of Andalusia. The 'antiquarians' were in charge of unveiling or revealing - that is, bringing to the fore - the traces of Christianity for their readers.

When Martín de Roa put the finishing touches on his Flos sanctorum, fiestas $i$ santos naturales de la ciudad de Cordoua, he was just returning from Rome, where he had spent 1611-12 as part of a congregation of Jesuit representatives (this was the only time he left Spain). Back in Cordoba, in 1613, the tomb of the aforementioned Juan del Pino, a local 'antiquarian' who had died with an aura of sanctity about him, had recently been opened on the occasion of the burial of Leonor Rodríguez, Pino's sister-in-law. According to legend, the body of this priest was discovered intact, which helped to corroborate his saintly reputation. After his death, and even to this day, Cordoban scholars refer to him as the 'venerable Juan del Pino'. For Martín de Roa at the beginning of

36 Mercedes García-Arenal and Fernando Rodríguez Mediano, The Orient in Spain: Converted Muslims, the Forged Lead Books of Granada and the Rise of Orientalism (Leiden: Brill, 2013). We will simply reproduce some lines of the introduction to recall this chapter of history: 'In the late sixteenth century there appeared in Granada, under miraculous circumstances, some small circular leaves of lead incised with strange, archaic Arabic letters like those used in epigraphic inscriptions, amulets, and magical formulas. The Lead Books provided evidence of the presence of Saint James in Spain and of the belief - which had not yet been declared a dogma of the Church - in the Immaculate Conception of Mary;' pp. 1-2. The most interesting aspect of this work, for our purpose, is the discussion in chapter 6 of the way Al-Andalus was incorporated into the History of Spain by scholars in the late sixteenth and the early seventeenth century. On the topic of relics, the child saints Justus and Pastor, transferred to Alcalá de Henares in 1567, serve as an example of continuity for Ambrosio de Morales, Felipe II's famous chronicler, in his book La vida, el martyrio, la invención, las grandezas y las translaciones de los gloriosos niños martyres San Iusto y Pastor (Alcalá de Henares: Blas de Robles, 1568), asserts: 'the chapel of the saints was always Christian, even in Moorish times, like many other churches that remained in Spain, where the Moors permitted their captives and subjects to join together in all the rites that our religion demands'; fols. 11v-12r. 
the seventeenth century, Pino's reputation as a saint was linked to his work as one of the authors of the diocesan liturgical office. But above all, for Martín de Roa as well as for the Catholic community of Cordoba, Pino's reputation was associated with the Revelaciones hechas al padre Roelas of 1578 , transcribed by him but held in secret until 16o1. His saintly reputation was what would make the Revelaciones a reliable source for all the scholars who, like Roa, would work to give body and substance to the diocesan liturgy that had been published in 1601.

Martín de Roa printed his Flos sanctorum in 1615. After the conclusion of the Council of Trent, the ecclesiastical authorities of Cordoba - just as in other regional churches - promoted the inclusion of the feast days of their own martyr saints in the martyrology and in the Roman breviary. Letters preserved in the Real Academia de la Historia attest to the epistolary exchanges between Bishop Reinoso of Cordoba, Cardinal Baronius, Juan del Pino and the Jesuit Juan de Pineda, who was in Rome at that time. ${ }^{37}$ The latter interceded in 1602-03 to have additional Cordoban saints recorded in the Roman breviary. It

37 Three letters are kept in the Real Academia de la Historia [RAH], 9/3666 (105). They show the leading part that Juan del Pino had in the 'identification' of the martyred-saints, the negociations with the Congregation of Rites for the inscription of their feast in the liturgy, and the promotion of the Revelaciones of Father Roelas that we will discuss futher on. We transcribe one of these letters, adressed from Juan del Pino to the Jesuit Juan de Pineda, of 1604: 'Muchas gracias sean dadas a nuestro señor, que ya mi padre Juan de Pineda dexo negociado en Roma lo que yo tantos años ha deseava de mis señores los santos de cordoba el de cabra S. Vuitesindo al qual solo no señalo san eulogio el dia de su Martyrio, queda ya señalado en santos de Mayo, y los santos Habundo, Marcos y compañeros de quien esta Santa Yglesia rezava de tiempo tan antiguo a 13 de julio, que quando se recibio el nuevo breviario Romano, los diputados del cabildo, sin aver cosa alguna en contrario (invicta causa) nos los quitaron del rezado, solo por no conocerlos, se remediara. Yo embie un calendario antiguo, que se arranco de breviario cordoves de ochenta años, con buena informacion, y sellos de la yglesia y ciudad, y testimonio de Rodrigo de Molina escrivano publico con fe de todo. y desde Granada rezien venido me escrivio mi padre Juan de Pineda lo siguiese. El santo de Cabra tiene ya dia señalado por el cardenal Baronio en mi presencia a los 15 de Mayo, los otros santos de cordoba del calendario y breviario antiguo quedara assimismo notado por mano del mismo cardenal para añadirse a el calendario romano a la primera impression y el cardenal muy agradecido a la memoria y oraciones de v. m. las hojas del calendario las buelvo a traer. E dicho todo esto por dos cosas, la una, porque como a v. p. le a costado el rezado de nuestros santos mas que a todos, quando se ofrezca ocasion ayude a concluyrlo, la $2^{\mathrm{a}}$ para que si es posible se escriva a valladolid pues de alli esta cerca Plazencia o burgos, para que se cobre del secretario de nuestro obispo Reynoso el breve que se llevo del rezado, que alla tiene tan inutil, y aca sera muy de provecho ... Amen al padre diego de herrera mis humildes beso manos de cordoba y de diziembre 18 de 1604. Juan del Pino'; [18 December, 1604]. 
seems that Martín de Roa had been associated with the "cause of the Cordoban saints' since at least 1583, when he composed six Latin hymns in honor of the martyred saints Acisclus and Victoria, Zoïlus, Eulogius and Pelagius, published in a short Latin work called De antiquitate et auctoritate Sanctorum Martyrum Cordubensium, first edited with the Officios propios de Cordoba of 1583 . He is clearly a member of a network of scholars who applied 'scientific' logic to the revision of liturgy and sacred history.

In his Flos sanctorum, fiestas $i$ santos naturales de la ciudad de Cordoba, published in 1615, Roa created a history that reprised the Crónica general of the royal chronicler Ambrosio de Morales, who is known to have settled back in Cordoba at the end of his life. ${ }^{38}$ As we have already mentioned, Ambrosio de Morales brought to the Christian history of Cordoba his deep knowledge of the works of St Eulogius, discovered in 1572 by fellow Cordoban Pedro Ponce de León in the Cathedral of Oviedo. St Eulogius' Memorialis Sanctorum, which told of the persecution of Christians by Muslims in ninth-century Cordoba and evoked the persecutions of the Roman period, had been published by Morales himself in $1574 .{ }^{39}$ The fifth book of his Crónica general also included the account of the persecutions endured by St Acisclus and St Victoria, the patron saints of Cordoba, in the Roman period, as well as those of Saints Faustus, Januarius and Marcial. ${ }^{40}$ In discussing the two chapters of the Crónica (book XIII, chapters 33 and 39) on the Cross of the Angels - a gilded Greek cross set with precious stones and ancient Roman coins that is still kept today in the royal chapel in Oviedo's cathedral - Lucia Binotti argues that 'the physical artifact reveals a set of concrete elements that serve to confirm or deny the miracle and that texts cannot compete with. This is one case where material observation takes precedence in verifying an event of the past and is a first step towards the development of a more rigorous, but less textually based method of scientific observation' ${ }^{41}$ The 'antiquarians' who worked to convert the Cordobans to

38 On Ambrosio de Morales, see Lucia Binotti, 'Coins, Jewelry and Inscriptions: Ambrosio de Morales and the Re-Writing of Spanish History', Hispanófila. Literatura-Ensayos, 57 (2009), pp. 5-24. Sebastián Sánchez Madrid, Arqueología y humanismo: Ambrosio de Morales (Cordoba: Universidad de Córdoba, 2002).

39 Diui Eulogii Cordubensis martyris ... Opera studio et diligentia (Alcalá de Henares: J. Íñiguez de Lequerica, 1574).

Florián de Ocampo, La Coronica general de España, que continuava Ambrosio de Morales (Alcalá de Henares: J. Iñiguez de Lequerica, 1574), and Los otros dos libros vndecimo y duodecimo de la Coronica General de España que continuaua Ambrosio de Morales (Alcalá de Henares: J. Iñiguez de Lequerica, 1577).

41 In her article, Lucia Binotti discusses the way in which Morales strove to develop a method of proof. For this quote, see Bonotti, 'Coins, Jewelry', pp. 15-16. 
the veracity of the martyrs' relics at the end of the sixteenth century and the beginning of the seventeenth century based their demonstration on material evidence. At the beginning of a chapter dedicated to the hagiography of St Acisclus and St Victoria in his Flos sanctorum dedicated to 'santos de Cordoba', Martín de Roa expressed his desire to help establish appropriate devotion based on 'natural reason' for 'rational martyrs', ${ }^{42}$ With him, the Cordoban Catholic community was using the material aspect of devotion for the relics in their reliquaries ${ }^{43}$ as instruments of proof. In the context of the CounterReformation, we see that Christian materiality, to use Caroline Bynum Walker's term ${ }^{44}$ was not only to be controlled by Catholic authorities - the commentaries made by scholars on the ${ }_{1563}$ Decree of the Council of Trent have enhanced it - but also potentiated. As already stated, in Spain scholars aimed to use the discovered vestiges to prove the continuity of the Christian past through a centuries-long martyrdom imposed first by Romans and later by Muslims, presented as enemies and executioners of the same type. For this purpose, it was essential for the Catholics to show the articulation between their discourse and their practices, between past and present. If there was no interruption, it would be because the Christian vestiges found in the soil were not dead but simply forgotten by the devotees. Vice-versa, if the Spanish past was continuous, the bones found in the same place as the martyrs' remains from Roman times were necessarily also the bones of martyrs. After the Council of Trent, in the face of Protestant critics, the search for veracity led the Catholic Church to demonstrate the relics' historicity. ${ }^{45}$

42 'DE LOS GLORIOSOS martires San Acisclo, i Santa Vitoria patronos de Cordoba. XVII de Novienbre. Sobre la justa piedad, i devocion, con que onramos las memorias de los Martires, a todos les devemos atencion de orejas, prontitud de lenguas, i aficion de animo; para oir con gusto, i hablar con acierto de sus alabanças, que nos inciten a el estudio de mejor vida: la razon natural, la divina Lei, los Profetas, los Apostoles, i el mismo Christo Señor nuestro primera regla, i dechado de los que despues, i antes padecieron por la justicia; no son enpero de menos provecho los Martires racionales, victimas perfetas, i ofrendas agradables, i aceptas a Dios; para regir los passos de nuestra peregrinacion, para ordenar la vida, i limar las costumbres'; Martín de Roa, Flos sanctorum, fol. 157r. For instance, Katie Harris recalls: 'the relic's ontological ambiguity, blending of the human and the divine, the alienable and the inalienable'; Harris, From Muslim to Christian Granada, p. 226.

Caroline Bynum Walker, Christian Materiality: An Essay on Religion in Late Medieval Europe (New York: Zone Books, 2011).

45 Dominique Julia: 'Le concile ouvre donc la voie à une vérification attentive des reliques de la part de l'autorité épiscopale, de manière à ne pas tomber sous le feu des critiques réformées: la quête de la véracité des reliques débouche sur la démonstration de leur historicité.' Also Julia, 'Léglise post-tridentine et les reliques. Tradition, controverse et critique 
In fact, a saint's relic is nothing without its authentication. The piece of paper, the authentica, is then inseparable from it. The 'antiquarians' were in charge of making it possible for the bones found in the old graves to be taken as archeological remains extracted from the soil that covered their ancient and buried truth. They had then to make them visible to the community of believers. By rekindling their devotion for them, like embers being fanned, the bones would be brought back to life, or be revealed like dark images made clear. But since in Cordoba there was neither a traditional cult to the new martyrs whose relics were supposedly found in 1575 - that is, no 'truth of devotion' - nor material evidence in the inscriptions, there was a need for divine authentication. The archangel Raphael appeared to Father Roelas to compensate the lack of historical proofs and then to impose the 'truth'. The angel's image, a figure clad in a white robe, was a thaumaturgical figure - he is, after all, known as medicinaDei in the Scriptures. ${ }^{46}$ Before 1601-03, the 'revelations' were not considered to be miraculous. They were only the texts of a statement registered by Juan del Pino for the diocesan authorities in 1578. They had juridical status, although virtual, as long as they were kept secret. But when the contents of Andrés de Roelas' deposition happened to be used by local authorities, and started to circulate, they proved at once the authenticity of the relics of the other saints who had been martyred in the Muslim period. The end of the plague demonstrated the special link between the holy city and the divine through the worship of the newly identified martyrs brought in procession in their reliquaries from San Pedro to the cathedral. The interesting point, too, is that the belief in the truth of these 'revelations' depended on the faith placed in the

(XVI ${ }^{\mathrm{e}}-\mathrm{XVIII}{ }^{\mathrm{e}}$ siècle)', in Reliques modernes. Cultes et usages chrétiens des corps saints des Réformes aux révolutions, (ed.) Philippe Boutry, Pierre Antoine Fabre and Dominique Julia (Paris: EHESs, 2009), vol. 1, p. 70.

46 As Émile Mâle recalled, an old representation of the seven archangels was discovered in 1516 on a fourteenth or fifteenth-century fresco under a whitewash in a Carmelite church of Palermo. A Latin inscription mentioned: Michael victoriosus, Gabriel nuncius, Raphael medicus, Barachiel adjutor, Jehudiel remunerator, Uriel fortis socius and Sealtiel orator. This discovery in Sicily was regarded as miraculous, and Emperor Carlos V as well as Viceroy Hector Pignatelli financed the building of a new church dedicated to the seven archangels in 1523. Antonio Lo Duca, parish priest of the church, went to Rome to propagate the new devotion, and in 1555 published a book entitled Septem Principum angelorum orationem et eorum misse. In 1541 he had also received a celestial revelation that the Baths of Diocletian would be the place where the cult of the seven archangels would be glorified in Rome. This is where a new church, commissioned to Michelangelo, was dedicated by pope Pius IV to Mary of the Angels in 1563 . See Émile Mâle, L'Art religieux de la fin du XVI ${ }^{e}$ siècle, du XVII ${ }^{e}$ siècle et du XVIII ${ }^{e}$ siècle, étude sur l'iconographie après le Concile de Trente. Italie, France, Espagne, Flandres (Paris: A. Colin, 1932), pp. 297-99. 
word of a pious man, Andrés de Roelas, ${ }^{47}$ exhibiting the same position as the one Acuña del Adarve used in the treatise about the Santo Rostro of Jaén that we have already discussed: Andrés de Roelas was simply a pious Christian, who had not asked to be the vehicle for these sacred 'revelations'. It also depended on one of the three archangels named in the Bible, Raphael, medicina Dei, having come to help the cause of the patria of the saints in those 'revelations'. Angelic intercession was the supreme argument for the relics' authenticity. In fact, it happens that in 1601 the image of the archangel Raphael was placed on the church tower in order that it might, together with the martyred saints, protect the city from the epidemic. Also, the thanksgiving that followed the procession of 1603 was accompanied by the commission of an image of St Raphael to be placed above the chapel of the martyrs of San Pedro by the cathedral chapter. From this moment, the cult of the archangel became entrenched in Cordoba, as Raphael's intercession was believed to have been instrumental against the plague.

The context of the epidemic in 1601-03 explains the need for more thaumaturgical intercessors in Cordoba. But although St Rock or St Sebastian were traditionally invoked against the plague, only the archangel Raphael's was called upon. In fact, parallel to this context, there was a phenomenon of expanding angel worship at the beginning of the seventeenth century throughout Christendom. This was the period when the very centre of the Catholic world promoted the cult of the Guardian Angel. Its feast ad libitum was decreed

47 I cite the version of these 'revelations' included in the book printed by Pedro Díaz de Ribas in 1650: El Archangel S. Rafael, particular custodio y amparo de la ciudad de Cordoua: prueuase con varios argumentos y en particular con las Reuelaciones del venerable presbytero Andres de las Roelas (Cordoba: Saluador de Cea Tesa, 1650), fol. 21v: 'Avía con la nueva invención del sepulcro y huessos dessos Santos Martyres refrescadose en mi este afecto y particular devoción y reafirmádome más en ella acerca de los dichos Santos, con que me criaron e instruyeron: y tenia por muy cierto que ellos eran los que allí nuestro Señor tan graciosamente y fuera de toda esperança nos avia descubierto y que en ninguna manera podian ser otra cosa que el tesoro que tengo dicho. Y con esta certidumbre y entera fe, de q. allí estavan viendome en la necessidad de salud y peligro grande ya dho y considerando las muchas necessidades y pobreça dentro y fuera de mi casa, a quien yo acudia y remediaba, por ser nro Señor servido de hazerme esta md., q así la conozco por don y misericordia suya, rogaba y suplicava cada dia en este tpo largo de mi enfermedad, que duró hasta víspera de Pasqua Florida deste año de setenta y ocho, a los dichos santos mártyres fuessen intercesores con Dios nuestro Señor me diesse salud para que con ella, y su favor pudiesse yo remediar necesidades de tantos. Y por cinco vezes, en distintas y diferentes noches, sin ver persona, ni vision alguna, paresció que me dezian, Salte al campo y tendrás salud'. 
by the Congregation of Rites in $1608 .{ }^{48}$ However, although it fell to the Guardian Angel to be the individual protector of the human soul, the archangels enjoyed just as much popularity, especially in the Spanish territories. When a second plague epidemic struck the city in 1649, the cult of all the archangels became truly widespread. In the first half of the seventeenth century, we can cite many pictorial series of archangels, like the ones preserved in the monasteries of Las Descalzas Reales and La Encarnación in Madrid, or in the chapel of St Michael in the Cathedral of Jaén. Following the development of an iconography of archangels, Spanish treatises on the seven archangels multiplied in the second half of the seventeenth century. ${ }^{49}$ It is in the context of this veritable explosion of angel worship, in all its forms, that Raphael became the protector of the city of Cordoba. ${ }^{50}$ The Jesuits aggressively promoted the angelic cult in Rome as well as in the rest of the Catholic world, but in Cordoba their efforts were particularly fruitful, as the archangel Raphael became the patron saint of the city. His election as the custodio for the town in the mid-seventeenth century would show that his intercession for Cordoba was unquestionably believed and wholeheartedly supported by the citizens.

We have already noted the influence of the Jesuits on the Cordoban 'antiquarians' through Martín de Roa and theologians Enrique Enríquez and Saelizes, both mentioned in the text of the Revelaciones del padre Roelas. ${ }^{51}$ If we look closer at the network of Cordoban scholars, we find that the theologian Francisco Suárez, an important figure who was a pupil of Enríquez at Salamanca, wrote a monumental treatise of angelology entitled De angelis (1621).52 Two works, following the election of Raphael as the patron saint of

48 Antoine Mazurek, 'Lange gardien à l'époque moderne. Culte, élaboration doctrinale et usages. $\mathrm{XVI}^{\mathrm{e}}-\mathrm{XVIII}{ }^{\mathrm{e}}$ siècles' (PhD Diss., Paris, EHESs, 2013). A feast ad libitum is a feast whose date is left to the decision of each diocese.

49 Tomás Sánchez, SJ, Las seis alas del Serafin en seis sermones de los seis Iueves de Quaresma, predicados en el Real Convento de la Encarnación (Madrid: Antonio Francisco de Zafra, 1679).

50 Jerónimo de Saona, Hyerarchia celestial y terrena y symbolo de los nueve estados de la Iglesia militante, con los nueve Choros de Angeles de la Triumphante (Cuenca: Cornelio Bodan, 1603).

51 Rafael Ramírez de Arellano, Ensayo de un catálogo biográfico de escritores de la provinciay diócesis de Córdoba con breve descripción de sus obras (Madrid: Tip. Revista de Archivos, Bibliotecas y Museos, 1921-23).

52 Francisco Suárez, SJ, Commentariorum ac disputationum in primam partem divi Thomae pars II, de Deo effectore creaturarum omnium, in tres praecipuos tractatus distributa, quorum primus de Angelis, Opera omnia, Vol. 2 (Mainz: H. Mylii Birckmanni, B. Lippius, [1621]). 
Cordoba, were part of the general promotion undertaken by the Society of Jesus in favor of the archangel. The first book, written by the Jesuit Rafael de Bonafé, is dated 1659: Títulos de excelencia y oficios de piedad del arcángel $S$. Rafael. ${ }^{53}$ The second is from 1683 and is called El médico perfecto san Rafael. It was written by Francisco García, the author of two short works on St Michael and St Gabriel, published that same year. ${ }^{54}$ The mediating power of the archangel Raphael, who had appeared to Father Roelas to identify the 'other' martyrs and was intensely promoted by the Jesuits, was such that he became the patron saint par excellence of the Cordoban community, the guardian angel of the city.

Raphael's image, used to prove the authenticity of so-called ancient relics at the beginning of the seventeenth century, was later worshipped for itself. His cult, which grew out of the protection his image provided in 1601-03, became more widespread with the second plague of the century, in 1649. Choosing the patronage of St Raphael for Cordoba was a process that took three-quarters of a century, between 1575 and 1650 , and was consolidated with the creation of a Confraternity of St Raphael in 1655, a municipal rather than ecclesiastical community. ${ }^{55}$ The Revelaciones of Father Roelas were printed and disseminated in $165^{\circ}$ in the work of a local scholar, Pedro Díaz de Ribas, commissioned by the municipal chapter, entitled El Arcángel San Rafael particular custodio y amparo de la ciudad de Córdoba. This work was used once again by local authorities in the battle which the city of Cordoba waged at that time. In October of 1649 , when the plague claimed its first victims in Cordoba, the municipal chapter voted on the decision to place itself under the protection of the archangel Raphael. The council first addressed itself to the bishop, Fray Pedro Tapia. The ecclesiastical chapter then joined forces with the municipality to make a request for the recognition of the cult as super cultum in Rome; they had to prove that the worship of Raphael was an age-old tradition, which the chapter did on the grounds that the image and the worship of the archangel Raphael

53 Rafael de Bonafé, Titulos de excelencia, y oficios de piedad del arcangel S. Rafael (Madrid: Francisco Nieto y Salçedo, 1659).

54 Francisco García, El medico perfecto San Raphael arcangel (Madrid: J. García Infançón, 1683); García, El embaxador de buenas nueuas San Gabriel arcangel (Madrid: J. García Infançón, 1683); and García, El primer ministro de Dios San Miguel Arcangel (Madrid: J. García Infançón, 1684).

55 The decret Pro patronis eligendis, of 1630 [publicated in Decreta authentica Congregationis Sacrorum Rituum ex actis eiusdem Sacr. Congr. Collecta, (ed.) Aloïs Gardellini (Rome: Bourlié, 1824), vol. 1, doc. 705] states that in the case of an urban patronage, the election of the patron must be pronounced by the city council in the name of the citizens and in agreement with the local clergy and the diocesal Church. 
dated from the medieval period. The Jesuit Martín de Escalante, then in Rome, received power from the municipal and diocesan chapters, as well as from the bishop, to lobby the Congregation of Rites. With the assistance of the procurador general (attorney general) of the Spanish provinces, Nuño de Villavicencio, Cordoba won its suit. The feast of the archangel Raphael, set on May 7 in commemoration of the day he appeared to Father Roelas, was decreed in Rome the same year. The ceremony chosen was that which Pope Sixtus V had given to the Mercedarians. The success of this campaign was cause for a celebration to mark the occasion and definitively seal the connection between Cordoba and Raphael: in thanksgiving, the city organized sumptuous celebrations, which were mentioned in the 1651 relaciones of Pedro Mesía de la Cerda and which included a poetry competition in honor of the archangel, bullfights, fireworks and two processions. One of the two processions carried the image of the archangel Raphael from the church of San Pedro, the church of the martyrs, to the cathedral, and then returned it to San Pedro.

The creation of the image of the archangel is a key element for the recognition of St Raphael as the custodio of Cordoba by its population. In 1652, Antonio del Castillo y Saavedra (1616-68) created an oil on canvas measuring $2.6 \times 2 \mathrm{~m}$ commissioned by José de Valdecañas y Herrera, a town council member (veinticuatro) of Cordoba (see fig. 4.1). This painting, originally placed above a jasper staircase in the former City Hall, is now in the collections of the Ayuntamiento of Cordoba. In a preliminary drawing kept in Cordoba's Museo de Bellas Artes, the archangel held a scepter, which was both an attribute of his monarchic status - he is called the 'prince of Heaven' 56 - and a sign that he governed the city which he protected. This object is not common in angelical iconography and made it difficult for spectators to immediately recognize the model. This is certainly why, in the final painting that was to be installed in City Hall, Antonio del Castillo replaced the scepter with a shield and added an inscription, which recalled the revelations made to Father Roelas. In fact, in the archangel's left hand, he holds a fish, in reference to the episode of Raphael and Tobias from the apocryphal Book of Tobias. Thanks to the presence of this fish, which also appears in the drawing, viewers could identify the figure at once. On the shield the archangel holds in his right hand, beneath the kneeling lion, the emblem of Cordoba, the following words were inscribed: 'I swear by Jesus Christ crucified that I am Raphael angel whom God has designated as the patron of this

56 Mindy Nancarrow and Benito Navarrete Prieto, Alonso del Castillo (Madrid: Fundación de Apoyo a la Historia del Arte Hispánico, 2004), in the chapter 'Antonio del Castillo. Dibujos preparatorios para composiciones', p. 92. 


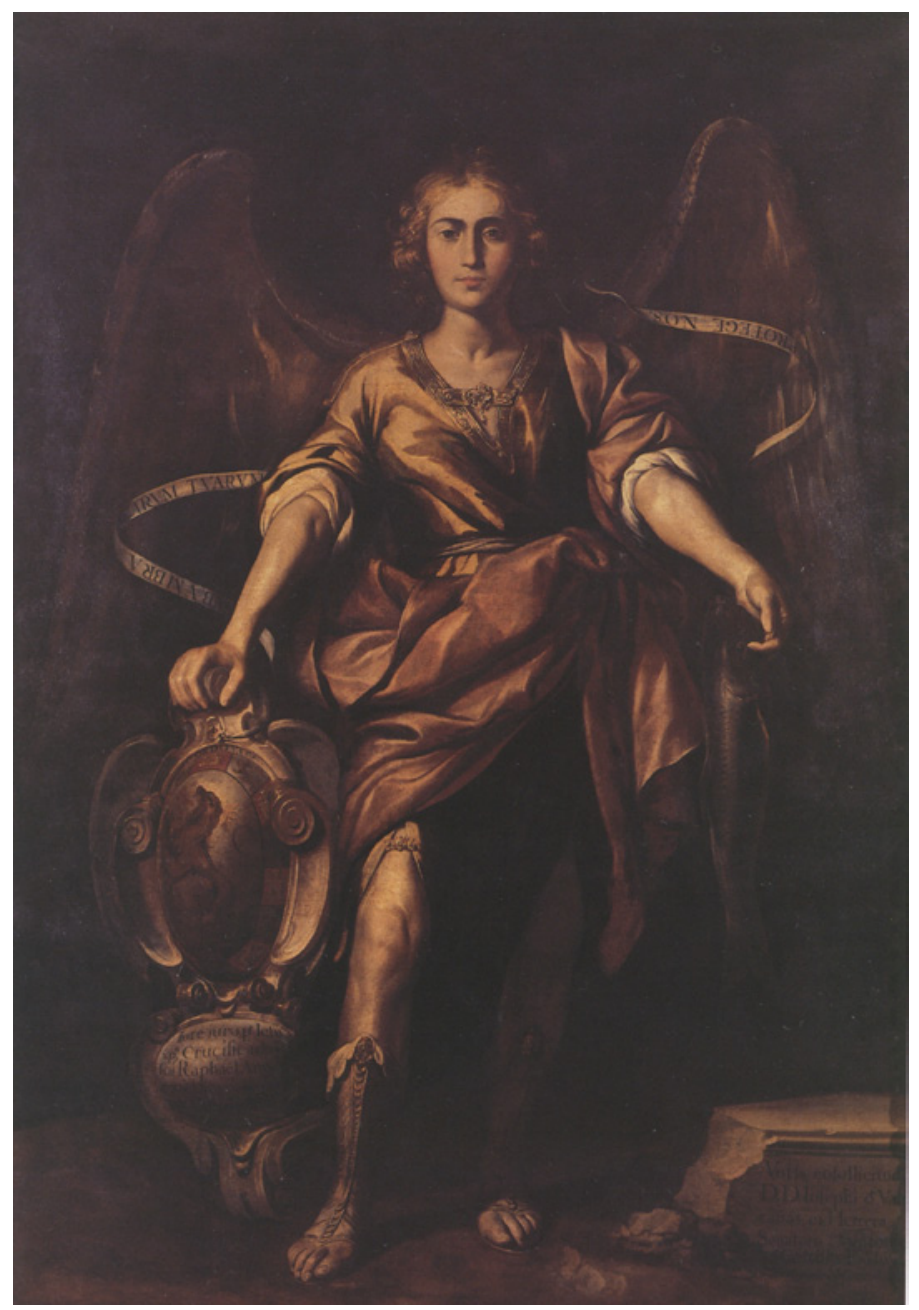

FIGURE 4.1 Antonio del Castillo y Saavedra, 'St Raphael', 1652, oil on canvas, $260 \times 200 \mathrm{~cm}$. Cordoba, Town Council.

town, ${ }^{57}$ that is, the phrase with which he proclaimed his name upon appearing to Father Roelas. Lastly, the names of the artist and the commissioner of the work, as well as the year $165^{2}$, appear at the bottom right of the painting. They remind us that this work was executed in commemoration of the civic celebrations that had taken place the previous year, when the Congregation of Rites had authorized the feast of St Raphael for Cordoba. A statue of the archangel

57 'Yo te juro por Jesucristo Crucificado que soy Rafael a quien Dios tiene por Custodio de esta ciudad de Córdoba'. 
had then been installed on the Roman bridge, which was thereby symbolically converted from a pagan symbol to a Christian one and would purify visitors as they entered the town of Cordoba. This second set of inscriptions, on the righthand side of the painting, show in what conditions the archangel Raphael was elected as the town's protector: 'Votis et sollicitudine D. Josephi Valde Cañas et Herrera Senatoris ... Antonius Castillo P.A. 1652'. What is even more remarkable is that these words are written on what is clearly a representation of an antique stone. The allusion to the sacred relics of the church of San Pedro is obvious. But this is not what strikes the spectator the most.

In this image, the custodio seems to have almost abandoned his celestial form to become incarnate, taking on a human appearance and facing outward, advancing toward the spectator. In fact, as Mindy Nancarrow and Benito Navarrete have noted, the figure is characterized by an imposing frontal presentation. With his two spread wings, he seems to have suspended his movement forward to pose for his portrait. As a matter of fact, this image recalls the images of Antonio del Castillo's master, Francisco de Zurbarán, who, as we know, painted female saints and angelic creatures as young women or men who seemed to be interrupted in their walk by a portraitist. ${ }^{58}$ This formal choice underscores the idea that the archangel has landed on earth and is present among Cordobans. In fact, paradoxically, the painter chose to suggest an interior setting, expressed by a neutral brown background where St Raphael stands facing forward. The view of the Guadalquivir and the famous Roman bridge of Cordoba that we find in some other representations has been erased. This is a way of projecting the archangel's protection onto every single one of the town's citizens, not only in the public arena, but also in private spaces.

In addition to being a representation of how Father Roelas would have seen Raphael in his visions, the frontal attitude is certainly one of Castillo's formal signatures. We can find it, for instance, in the many images of the Immaculate Conception that he painted, in his St Peter and St Paul, ${ }^{59}$ or in his San Ramón Nonato. ${ }^{60}$ But here it is combined with the representation of the archangel in a warrior-like dress, placing the viewer in a face-to-face situation that makes him

$5^{8}$ I have discussed these choices of representation in Vincent-Cassy, Les saintes vierges et martyres dans l'Espagne du XVII e siècle. Culte et image (Madrid, Casa de Velázquez, 2011). Nancarrow and Navarrete, Antonio del Castillo, Catalogue no. 13, 167 and no.14, 169. Both paintings are kept in the Cordoban Hospital de la Caridad, main altar. We can also mention his Saint John the Baptist, Madrid, colección Arango, no. 3 of the Catalogue, 151.

6o Numerous images of The Immaculate Conception are visible in this catalogue. Two of them are kept in the Cathedral of Cordoba, no. 46, 229, no. 48 of the Nancarrow and Navarrete catalogue, 233. See San Ramón Nonato, no. 111 Nancarrow and Navarrete Catalogue, no. 112 . 
or her feel the evidence of what he or she sees. The vision referred to in the texts printed by Pedro Díaz de Ribas merges with the painting. In fact, this image is intended to be a translation of the personal vision Father Roelas had of the archangel Raphael. It gives the spectator the illusion of being the receptor of this vision. By doing so, the viewer experiences the revelations. ${ }^{61}$ The 'a-narrative' 62 background gives another meaning to the image. Its focus is on reception and the experience of worship.

The painting served as the model for all the local engravers who helped disseminate the image. Castillo also produced a version of his image of Raphael on parchment for the 'Rules, Statutes, and Constitution' of the Confraternity of the Archangel in 1655 . With these images we can see that the mediation of the angel was no longer ensured by an ecclesiastical body but rather by the municipal body and the confraternity, whose headquarters were in City Hall. By using the archangel Raphael, the seventeenth-century civil power took on a selfappointed grandeur, in the form of a cult that was complimentary to but distinct from that of the martyred saints, whose relics played such an important role in Raphael's emergence in Cordoba.

Apparently, this cult, unlike that of the saints, did not rely upon the veneration of relics, but on visions and their artistic representation. If we take a new look at Antonio del Castillo's painting, we realize that the inscriptions visible on an apparently antique stone at the bottom right corner are a clear allusion to the ones that were found on the supposed martyr tombstones at the church of San Pedro in 1575. But beyond this allusion, they refer to the patron, the artist and the context of this commission. In fact, they underscore the connection between relics and images since the decree of the Council of Trent. The inscriptions were needed in Cordoba to authenticate the relics. As so, they were used as proof of the genealogical continuity between an idealized community of Christian exiles during the period of Muslim rule and the contemporary period of Martín de Roa and his 'antiquarian' companions. ${ }^{63}$ But in the end, it is the 'true' devotion to St Raphael, as expressed in the revelations to Father Roelas that was capable of producing evidence, which seems to be a paradoxical

61 For this reason, I do not agree with the idea that the figure itself is a mix of a true human being and a stone statue which, as Nancarrow and Navarrete assert, would remind us that this painting was commissioned after the 1651 feasts.

62 I use this neologism to mean that time and narration are suspended in the representation. For the definition of this category applied to Zurbarán's paintings of martyred saints and angels, see Vincent-Cassy, Les saintes vierges et martyres.

63 On this question, see Jocelyn N. Hillgarth, 'Spanish Historiography and Iberian Reality', History and Theory, 24 (1985): pp. 23-43; and Hillgarth, The Mirror of Spain, 1500-1700: The Formation of a Myth (Ann Arbor: The University of Michigan Press, 2000). 
continuation of the scientific methods promoted by Ambrosio de Morales and his epigones. In fact, what else is necessary to prove the truth of the sacred image but the efficacy of its mediation? The discourse elaborated by the Cordoban 'antiquarians' supported the Catholic theology of the image as it was discussed after the Reformation, and vice-versa. ${ }^{64}$ They founded their search for truth on what we would consider today non-scientific evidence: the obviousness of the angelic image revealed to a saintly man, the self-identified man in a white robe that Andrés de Roelas had spoken about in his Revelaciones. The truth of his existence is embodied by Antonio del Castillo's $165^{2}$ image [see fig. 4], which 'speaks' to the viewers. In this case, the veracity, which cannot rely on historicity, is based on piety for a true image of the invisible. This is what the frontal painting of the archangel Raphael made clear some fifty years after the Catholic authorities of Cordoba used the Revelaciones for the first time in 1601-03.

In fact, Antonio del Castillo's image puts the viewer in a position to experience the angelic intercession through present veneration. Also, as we have seen, the discourse elaborated by the Cordoban 'antiquarians' supported the Catholic theology of the image as it was discussed after the Reformation: the image was taken as material evidence. In fact, the archangel had immediately become an image offered to public veneration on the tower of the cathedral in 1601. This idea of 'revelation' is a key one for understanding Catholic worship in Spain after the Council of Trent. In Cordoba, it ended up creating an entirely new cult to the archangel Raphael who, in his theological definition, was himself an instrument of divine revelation. First and foremost, the contents of the Revelaciones were made necessary by the need to ultimately prove the continuity of the Christian past in the years following the Council of Trent and the liturgical revision of the breviary. The speaking angelic image that revealed to the parish priest the religious truth of the discovered relics was used at the beginning of the seventeenth century, as well as in 1650, to impose new intercessors when the plague struck the city. But in the third period, the midseventeenth century, it was not the relics but the image of St Raphael, elected custodio of the city in the middle of the seventeenth century, that succeeded in impressing upon the faithful its authenticity, as Antonio del Castillo's painting shows.

64 la théologie protestante dénie à la culture religieuse catholique toute articulation vivante entre son discours et ses pratiques, qui ne seraient que les vestiges (ou superstitions, monuments, restes) d'une foi éteinte ... [Elle] présuppose pour elle-même l'articulation naturelle de sa doxa et de sa praxis'; Fabre, Décréter l'image? p. 49. 


\section{PART 2}

Iberian Polemics, Readings of the Qur'ān and the Rise of European Orientalism 